\title{
Preliminary Study on the Distribution of Irrawaddy Dolphin, Orcaella brevirostris, in Banten Bay
}

\author{
Muta Ali Khalifa1, Mohammad Mukhlis Kamal1*, Enan Mulyana Adiwilaga', \\ Adriani Sunuddin'2 \\ ${ }^{1}$ Departement of Aquatic Resources Management, Bogor Agricultural University, Bogor, Indonesia \\ ${ }^{2}$ Department of Marine Science and Technology, Bogor Agricultural University, Bogor, Indonesia \\ Email: m mukhliskamal@yahoo.com
}

Received 18 July 2014; revised 7 September 2014; accepted 22 September 2014

Copyright (C) 2014 by authors and Scientific Research Publishing Inc.

This work is licensed under the Creative Commons Attribution International License (CC BY).

http://creativecommons.org/licenses/by/4.0/

(c) (i) Open Access

\section{Abstract}

Irrawaddy dolphins (Orcaella brevirostris) are aquatic mammals with critically endangered status able to live in different water salinities habitats, like estuary, rivers and lakes. Banten Bay features estuarine area where rapid economic development, contributed from industry, ports, mining and fisheries, takes place, and thus the presence of Irrawaddy dolphins in the area faces various environmental threats. This research aimed to study the distribution of Irrawaddy dolphins in Banten Bay and explore environmental factors threatening its life. Dolphins observation was conducted from January 2013-February 2014, using direct visual effort by team of observer and indirect effort by local fishermen. Direct visual effort was performed on boat by three observers, with maximum vessel speed $15 \mathrm{~km} /$ hour and total length of transect was $404 \mathrm{Km}$. Indirect visual effort comprised of regular assessment by 32 local fishermen when they conducted capture fishing at two different areas (South and North of Banten Bay). Sightings data from direct and indirect visual observation compiled with respondents opinion were mapped using Arc View ${ }^{\circledR}$ GIS 3.3, resulting in distribution map of Irrawaddy dolphin in Banten Bay. Irrawaddy dolphin was most frequently observed in the northeast, south and central areas of the bay. Environmental threats alarming the lives of Irrawaddy dolphin in the Banten Bay may include noise pollution, boat accident and entanglement.

\section{Keywords}

Banten Bay, Distribution, Environmental Threats, Irrawaddy Dolphin

\footnotetext{
*Corresponding author.

How to cite this paper: Khalifa, M.A., Kamal, M.M., Adiwilaga, E.M. and Sunuddin, A. (2014) Preliminary Study on the Distribution of Irrawaddy Dolphin, Orcaella brevirostris, in Banten Bay. Open Journal of Marine Science, 4, 338-343. 


\section{Introduction}

Banten Bay is a small bay with $150 \mathrm{Km}^{2}$ large area and 30 meter maximum waters depth. However, coastal activities at Banten Bay increase rapidly [1] [2]. East and South coasts of Banten Bay are dominated by mariculture with milk fish ponds, residential community and agriculture farm. Massive industrial development and intense activities in the international harbors took place in the western coast. Capture fisheries with several types of fishing gear took place in all parts of the Bay.

Irrawaddy dolphin (Orcaella brevirostris) can live in several types of aquatic habitats, like estuarine waters, rivers and lakes. Rudolph et al. (1997) [3] noted that Irrawaddy dolphins were distributed in some Indonesian’s estuarine waters, namely South Coast of Java Island (Segara Anakan), Seribu Islands, Surabaya Coast, East Kalimantan Coast [4], East part of Sumatera and Coast of Biak. Irrawaddy dolphin were also distributed in several rivers in Kalimantan, which were Mahakam River [5] [6], Barito River and Kajan River and Semayang Lake [7]. Irrawaddy dolphin categorized Vulnerable and certain sub-population Critically Endangered by International Union for Conservation of Nature and Natural Resources (2012) [8]. Convention on International Trade in Endangered Species of Wild Fauna and Flora (2013) [9] categorized Irrawaddy dolphin in Appendix I. Indonesian government made rules to conserve Irrawaddy dolphin with Indonesian Government Rules Number 7 year 1999 [10].

Banten Bay is predicted as one of Irrawaddy dolphin's habitats. Local fishermen note that they often see Irrawaddy dolphin in the Bay. They called Irrawaddy dolphin with Persut or Wersut. However, there is no scientific information about Irrawaddy dolphin presence in this bay. The aim of this research was to identify the distribution of Irrawaddy dolphin in Banten Bay and explore environmental factors threatening its life.

\section{Materials and Method}

This research was carried out from January 2013 until February 2014 in Banten Bay. Visual survey was perform with two types of observation: 1) Direct observation with visual surveyed along designated line transect across Banten Bay; 2) Indirect observation with participatory surveyed with two types of fishermen and fishermen interviewed.

Visual survey used small boats with maximum speed, $15 \mathrm{~km} /$ hour. Total distance covered for visual survey was 404 km. GPS (Garmin GPSMAP 78s) was used to guided ship navigation and record Irrawaddy dolphin’s sightings location. Observer used binoculars for observe Irrawaddy dolphin. Photo-identification conducted with Nikon D90 and NIKKOR 18 - 200 mm lens. Each survey was conducted observations of 2 - 3 days. Observations began at 7:00 a.m. until 2:00 p.m. Observations made during fine weather (beaufort scale less than 6). If weather gets worse, the observations were stopped

Direct survey was conducted with three observer along designated line transect across Banten Bay (Figure 1). First observer, using binoculars; Second observers, without binoculars; Third observer, ship tracks navigation, time reminder and filled data sheet. Observation efforts noted in effort data sheet. Every 15 minutes, observer position changed.

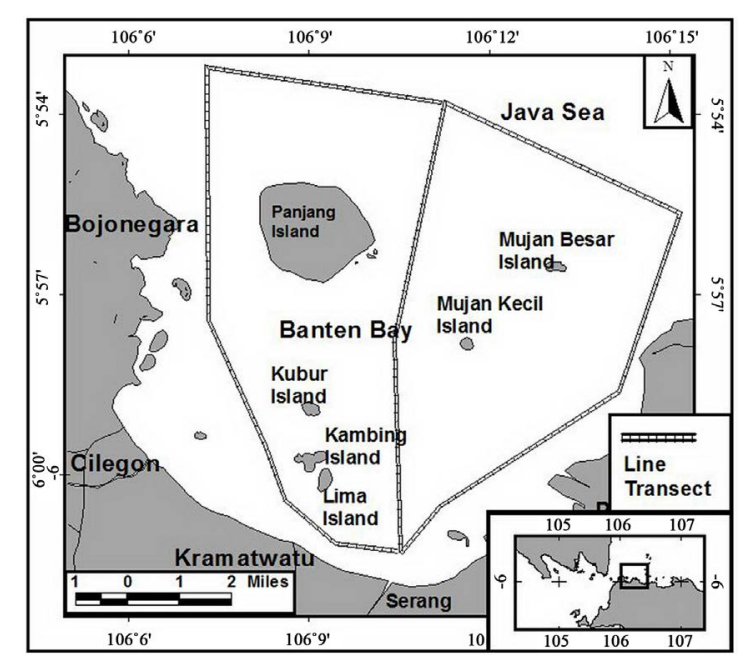

Figure 1. Research area in the Banten Bay, Northwest of Java, Indonesia. 
Participatory survey during January 2013-February 2014 involved two types of fishermen group who conduct daily fishing and each group had different fishing area in Banten Bay. The location of fishing area for the first group was located in the North part of the Bay, while the second group was in the South. Previously, the fishermen were trained to recognize Irrawaddy dolphin presence, then record the location and time of the sighting.

Participatory Survey involves two types of fishermen who daily fishing and had different fishing area inBanten Bay. First fishermen have fishing area in the North part of the Bay and the second fishermen in the South part of the Bay. Previously, the fishermen trained to recognize Irrawaddy dolphin presence, then recorded the location and time of the sighting.

There were 32 respondents who participated in this research, belonging to two groups of fishermen with different fishing area and fishing gear. Each respondent was interviewed about the Irrawaddy dolphin distribution in Banten Bay and their perception on dolphin presence in relation to their fishing activity. Information on Irrawaddy dolphin sightings location from all respondents were compiled and analyzed by Microsoft ${ }^{\circledR}$ Excel 2010 into percentage of fishermen opinion on the distribution of Irrawaddy dolphin in Banten Bay.

Map of Irrawaddy dolphin spatial distribution in Banten Bay was generated by Arc View ${ }^{\circledR}$ GIS 3.3 using baseline data of sightings in the bay. Baseline data were geo-reference data resulted from direct and indirect visual survey and complemented with information from fishermen interviewed, which also transformed into percentage of dolphin distribution site.

\section{Results}

During this research, direct visual observation was conducted in four periods representing all monsoonal season. Each survey was lasted for three days for conducting visual efforts and resulted in two sightings of Irrawaddy dolphins. The first was during northwest monsoon in February 2013 with large group of individuals in the Southeast of Banten Bay. In daylight hours, starting at 11:00 a.m. local time, up to 15 individuals of dolphins were sighted for more than one hour performing various type of behavior. The second sighting took place in the East of Banten Bay during transitional monsoon season with small group size (Table 1).

According to respondent, Irrawaddy dolphin can found in Banten Bay. Respondent answer that Irrawaddy dolphin can be found at Northeast until East (49\% Respondent answer), South (25\%), Southeast (17\%) and at the Central of the Bay (9\%). There is no information of Irrawaddy dolphin sightings at West and North of the Bay. Spatial information from respondent is shown at Figure 2. Irrawaddy dolphin can observe throughout of the year, especially in good weather.

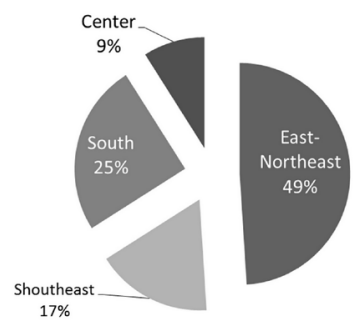

Figure 2. Respondent opinion about Irrawaddy Dolphin's spatial distribution in Banten bay.

Table 1. Result from direct and indirect of visual observation.

\begin{tabular}{|c|c|c|c|c|c|c|}
\hline No & Date & Time (GMT + 7) & Sightings Location & Object & Ind. Total & Behavior \\
\hline \multicolumn{7}{|c|}{ Direct Visual Observation } \\
\hline 1 & February 13, 2013 & 11:00 a.m. & Southeast of the Bay ${ }^{1}$ & ${ }^{1}$ O. brevirostris & $10-15$ & Travelling, Breaching, Breathing, Lobtailing \\
\hline 2 & September 27, 2013 & 08:00 a.m. & East of the Bay ${ }^{2}$ & O. brevirostris & 2 & Travelling \\
\hline \multicolumn{7}{|c|}{ Indirect Visual Observation } \\
\hline 3 & January 2013 & 3:00 p.m. & Central of the Bay ${ }^{3}$ & O. brevirostris & 2 & Travelling \\
\hline 4 & Mei, 2013 & 09:00 a.m. & South of the bay ${ }^{4}$ & O. brevirostris & $10-15$ & Travelling \\
\hline 5 & February 23, 2014 & 06:00 - 07:00 a.m. & South of the bay ${ }^{4}$ & O. brevirostris & 3 & Travelling \\
\hline 6 & February 25, 2014 & 06:00 - 07:00 a.m. & South of the bay ${ }^{4}$ & O. brevirostris & 1 & Travelling \\
\hline 7 & February 27, 2014 & 06:00 - 07:00 a.m. & South of the bay ${ }^{4}$ & O. brevirostris & 4 & Travelling \\
\hline
\end{tabular}




\section{Discussion}

According to all respondents interviewed during participatory survey in this research, the majority of Irrawaddy dolphins were sighted in the East to Northeast (49\%) and South (25\%) of Banten Bay (Figure 2). These findings conform to result obtained from direct and indirect visual observation (Table 1). Additionally, several respondents mentioned in detail the localities of dolphin sighting sites, e.g.: around Lima Island and Mujan Kecil Island, which located in the South and Central Banten Bay. Compilation of respondents' opinion and visual survey results from Irrawaddy dolphin sighting sites in Banten Bay are shown in Figure 3.

The estuarine area where most Irrawaddy dolphin were sighted had shallow depth (1 - 9 meters) with high turbidity [2] as affected by several rivers channeling in the Banten Bay, i.e. Ciujung, Cibanten, Cikaduen. Irrawaddy dolphin in Malampaya (Philippines) also distributed in shallow waters less than six metres [11]. In the waters of estuaries in East Kalimantan, Irrawaddy dolphins are spread at 5 - 14 metres depth [4].

There is no information about Irrawaddy dolphin presence in the west of the Bay. There were two possibilities: Irrawaddy dolphins did not exist in that area or fishermen did not know presence of Irrawaddy dolphin there because fishermen did not operate in that area. This condition is due to developed industrial and international harbor there.

Irrawaddy dolphin shows high sensitivity to noise pollution, ranging from roaring sound of ship's engine, intense ship and boat traffics, to construction development in the coasts [5] [12] [13]. Other potential dangers related with ship traffic or high velocity of boat maneuver would be injury due to ship strike or propeller hit. Irrawaddy dolphin might show adaptive behavior related with noise pollution and ship traffic, for example performing long dive and brief surfacing for breathing [12], or suddenly changing its course to avoid the area [5]. Irrawaddy dolphin also might be greatly affected by noise pollution, because most of its activities are relying on sound perception and biosonar activities by melon organ, whether just travelling or foraging for prey.

Deformed dorsal fin shown in Figure 4 is also founded in Irrawaddy dolphin in Bangpakong waters, Thailand

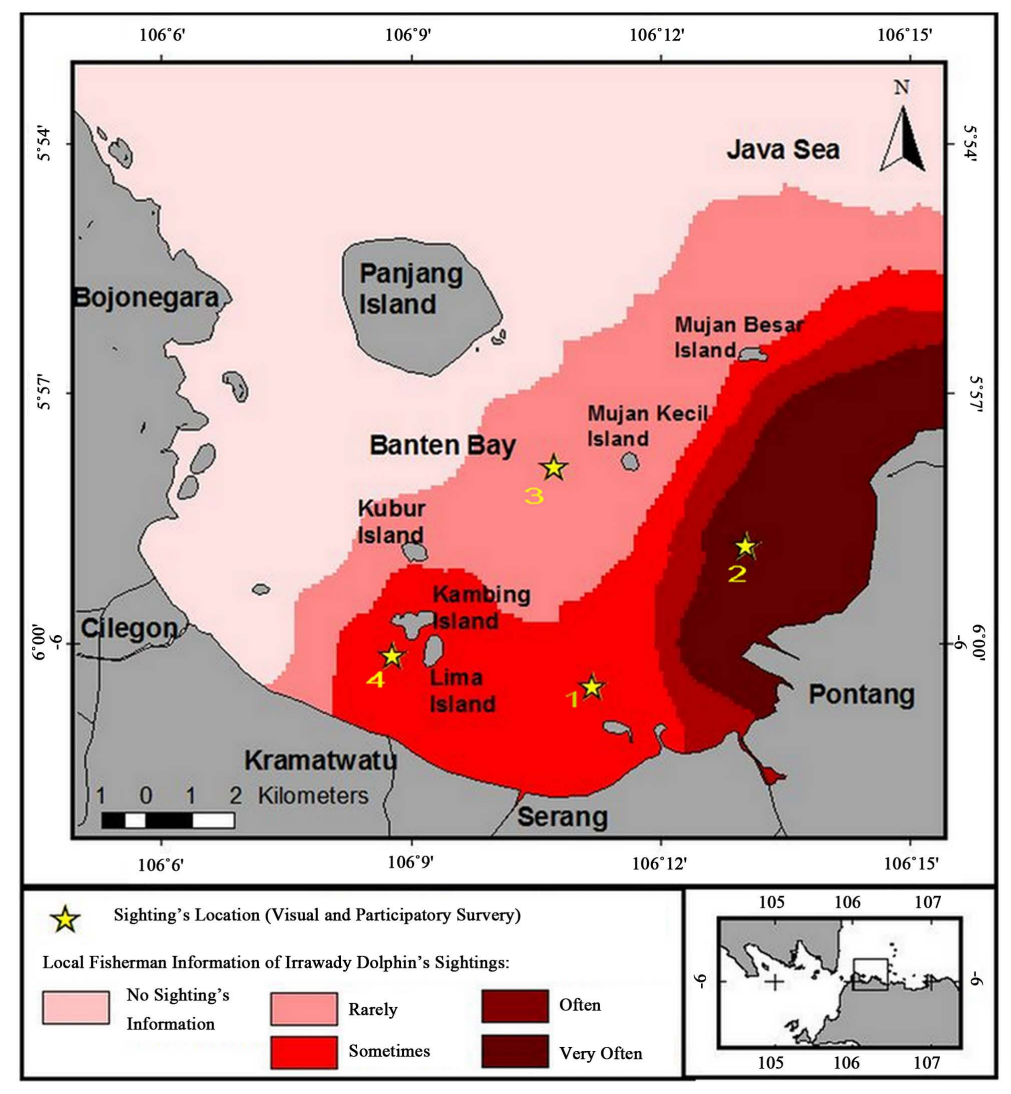

Figure 3. Spatial Distribution of Irrawaddy Dolphin in Banten Bay (Noted: Number of Asterisk Refer to Superscript Number at Table 1). 


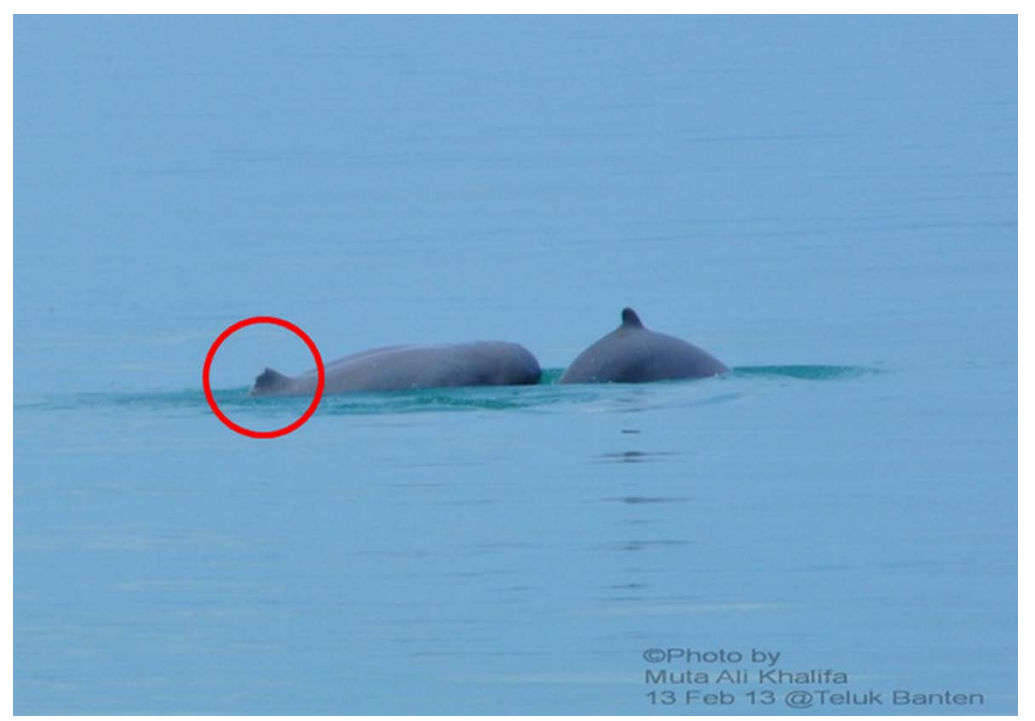

Figure 4. Circle in red is one dolphin showing physical defect on its dorsal fin.

[14]. According to Tongnunui et al. (2011) [14], this condition is due to accidental exposed ship propeller. Besides that, deformed dorsal fin could be caused by predator bite [15] [16]. Fishermen in Banten Bay said that Irrawaddy dolphin was not an enemy to them. This statement is due to local culture that Irrawaddy dolphins and human have same ancestors. Therefore fishermen always care viability of Irrawaddy dolphin. There is no information about Irrawaddy dolphin entanglement at fishermen gill net or hit by fishermen boat. It is not as the case in Mahakam River [5], the Mekong River [17], Songkhla Lake [18]; Irrawaddy dolphin was found to be dead due to entanglement in Fishermen gill net.

Irrawaddy dolphin is sighted in Banten Bay in almost all of seasons in Indonesia. Respondent also said that Irrawaddy dolphin could be observed throughout the year. It is indicated that Banten Bay is one of resident habitats for Irrawaddy dolphin. All of data from visual survey and participation showed that Irrawaddy dolphin could be observed in the morning, only one sighted Irrawaddy dolphin in evening. Tas'an and Leatherwood (1984) [7]; Stacey and Hvenegaard (2002) [12] also found diurnal movement of Irrawaddy dolphin, most often in the morning and it decreased towards evening. Besides that, daily movement of Irrawaddy dolphin also related with water level. Kreb (1999) in Stacey and Hvenegaard (2002) [12] found Irrawaddy dolphin most often in areas from medium to low water level and Beasley (2007) [19] found them in slow current. Indonesian Research Institute (2001) [20] said between 01:00 p.m. and 05:00 p.m. there occurred strong tidal current into Banten Bay to increase water level.

Small group size of Irrawaddy dolphin was ranged from 1 to 4 individuals. During the survey, two sightings of Irrawaddy dolphin showed large group size (about 15 individuals). Jefferson et al. (1993) [21] and Priyono (2001) [6] also said that Irrawaddy dolphin was commonly seen to have only maximum six individuals but sometimes up to 15 individuals when seen together.

From seven sightings records resulted from this research, 86\% showed travelling behavior of Irrawaddy dolphin in the Banten Bay. One indication on the importance of Banten Bay as critical habitat for Irrawaddy dolphin was one sighting record showing complex behavior up to 15 individuals. That is cooperative foraging behavior which is reflected by simultaneous activity of lobtailing, breaching and group travelling [15]. Thus, Banten Bay may serve as an important feeding habitat for Irrawaddy dolphin.

\section{Acknowledgements}

This research sponsored by Education Fund Management Institution, Ministry of Monetary, Indonesia and High Education Directorate, Ministry of Education, Indonesia. This research supported by Bogor Agricultural University and Karangantu National Fishing Harbour, Indonesia.

\section{References}

[1] Booij, K., Hillebrand, M.T.J., Nolting, R.F. and Van Ooijen, J. (2001) Nutrients, Trace Metals, and Organic Contami- 
nant in Banten Bay, Indonesia. Marine Pollution Bulletin, 42, 1187-1190. http://dx.doi.org/10.1016/S0025-326X(01)00214-4

[2] Hoekstra, P., Lindeboom, H., Bak, R., Van Den Bergh, G., Tiwi, D.A., Douven, W., Heun, J., Hobma, T., Hoitink, T., Kiswara, W., Meesters, E., Noor, Y., Sukmantalya, N., Nuraini, S. and Van Weering, T. (2003) TelukBanten Research Programme: An Integrated Coastal Zone Management Study (1995-2001). Proceeding of a Workshop Held on 12 February 2002: Scientific Programme Indonesia-Netherlands, Bandung (ID).

[3] Rudolph, P., Smeenk, C. and Leatherwood, S. (1997) Preliminary Checklist of Cetacea in the Indonesian Archipelago and Adjacent Waters. National Natuurhistorisch Museum, Leiden (ND).

[4] Kreb, D. and Budiono (2005) Cetacean Diversity and Habitat Preferrences in Tropical Waters of East Kalimantan, Indonesia. The Raffles Bulletin of Zoology, 53, 149-155.

[5] Kreb, D. and Noor, I.Y. (2012) Abundance and Threats Monitoring Surveys during Low Water Levels July and September 2012. Pesut Mahakam Conservation Program Technical Reports. Yayasan Konservasi RASI. Samarinda.

[6] Priyono, A. (2001) Lumba-lumba di Indonesia [Dolphins in Indonesia]. Faculty of Forestry Bogor Agricultural University dan, The Gibbon Foundation Indonesia, Bogor (ID).

[7] Tas'an and Leatherwood, S. (1984) Cetaceans Live-Captured for Jaya Ancol Oceanarium, Djakarta, 1974-1982. International Whaling Commission, Document SC/35/SM2: 485-489.

[8] (2012) [IUCN] International Union for Conservation of Nature and Natural Resources. The IUCN Red List of Threatened Species. http://www.iucnredlist.org/.

[9] (2013) [CITES] Convention on International Trade in Endangered Species of Wild Fauna and Flora. Appendices I, II, and III. CITES, Geneva (CH).

[10] Indonesian Republic President (1999) Indonesian Government Rules Number 71999 about: Flora and Fauna Conservation. Jakarta (ID).

[11] Dolar, M.L.L., Perrin, W.F., Gaudiano, J.P., Yaptinchay, A.A.S.P. and Tan, J.M.L. (2002) Preliminary Report on a Small Estuarine Population of Irrawaddy Dolphins Orcaella brevirostris in the Philipines. The Raffles Bulletin of Zoology, 10, 155-160.

[12] Stacey, P.J. and Hvenegaard, G.T. (2002) Habitat Use and Behavior of Irrawaddy Dolphin (Orcaella brevirostris) in the Mekong River of Laos. Aquatic Mammals, 28, 1-13.

[13] Hashim, N.A.N. and Jaaman, S.A. (2011) Boat Effects on the Behavior of Indo-Pasific Humpback (Sousa chinensis) and Irrawaddy Dolphin (Orcaella brevirostris) in Cowie Bay, Sabah, Malaysia. Sains Malaysiana, 40, 1383-1392.

[14] Tongnunui, S., Wattanakornsiri, A., Pachana, K., Beamish, F.W.H. and Tongsukdee, S. (2011) Preliminary Investigation of Irrawaddy Dolphin (Orcaella brevirostris) in the Bangpakong Estuary, Inner Gulf of Thailand. Environment and Natural Resources Journal, 9, 48-57.

[15] Heithaus, M.R. and Dill, M.L. (2009) Feeding Strategies and Tactics. In: Perrin, W.F., Würsig, B. and Thewissen, J.G.M., Eds., Encyclopedia of Marine Mammals, 2nd Edition, Elsevier Inc., Oxford.

[16] Khan, M., Panda, S., Pattnaik, A.K., Guru, B.C., Kar, C., Subudhi, M. and Samal, R. (2011) Shark Attacks on Irrawaddy Dolphinin Chilika Lagoon, India. Journal of the Marine Biological Association of India, 53, 27-34.

[17] Baird, I.G. and Mounsouphom, B. (1994) Irrawaddy Dolphins in Southern Lao PDR and Norteastern Cambodia. Natural History Bulletin of Siam Society, 42, 159-175.

[18] Beasley, I., Chooruk, S. and Piwpong, N. (2003) The Status of The Irrawaddy Dolphin, Orcaella brevirostris, in Songkhla Lake, Southern Thailand. Raffles Bulletin of Zoology, 10, 75-83.

[19] Beasley, I.L. (2007) Conservation of the Irrawaddy Dolphin, Orcaella brevirostris (Owen in Gray, 1866) in the Mekong River: Biological \& Social Considerations Influencing Management. Ph.D Thesis, James Cook University, Queensland.

[20] Indonesian Research Institute (2001) Laporan Penelitian Wilayah Pesisir Teluk Banten Tahap Kedua (Banten Bay Coastal Area Second Phase Research Report). Indonesia Research Institute, Jakarta.

[21] Jeffferson, T.A., Leatherwood, S. and Webber, M.A. (1993) FAO Species Identification Guide-Marine Mammals of the World. The Expert center for Taxonomic Identification (ETI), University of Amsterdam, Amsterdam. 
Scientific Research Publishing (SCIRP) is one of the largest Open Access journal publishers. It is currently publishing more than 200 open access, online, peer-reviewed journals covering a wide range of academic disciplines. SCIRP serves the worldwide academic communities and contributes to the progress and application of science with its publication.

Other selected journals from SCIRP are listed as below. Submit your manuscript to us via either submit@scirp.org or Online Submission Portal.
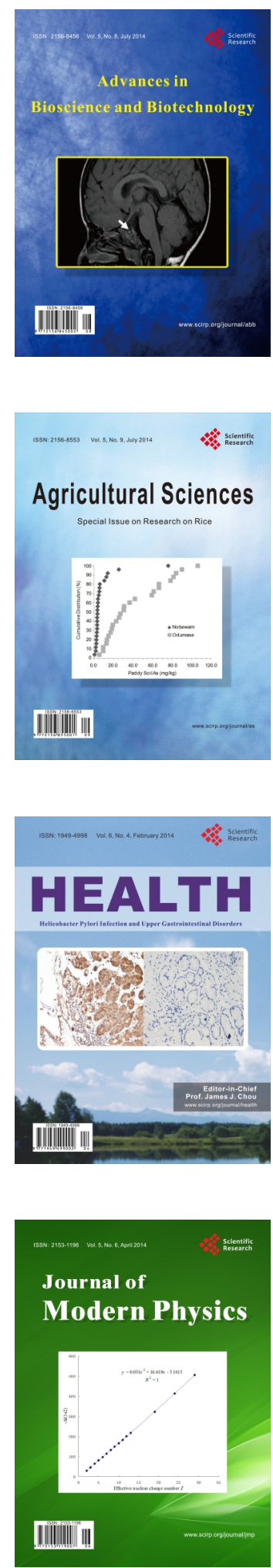
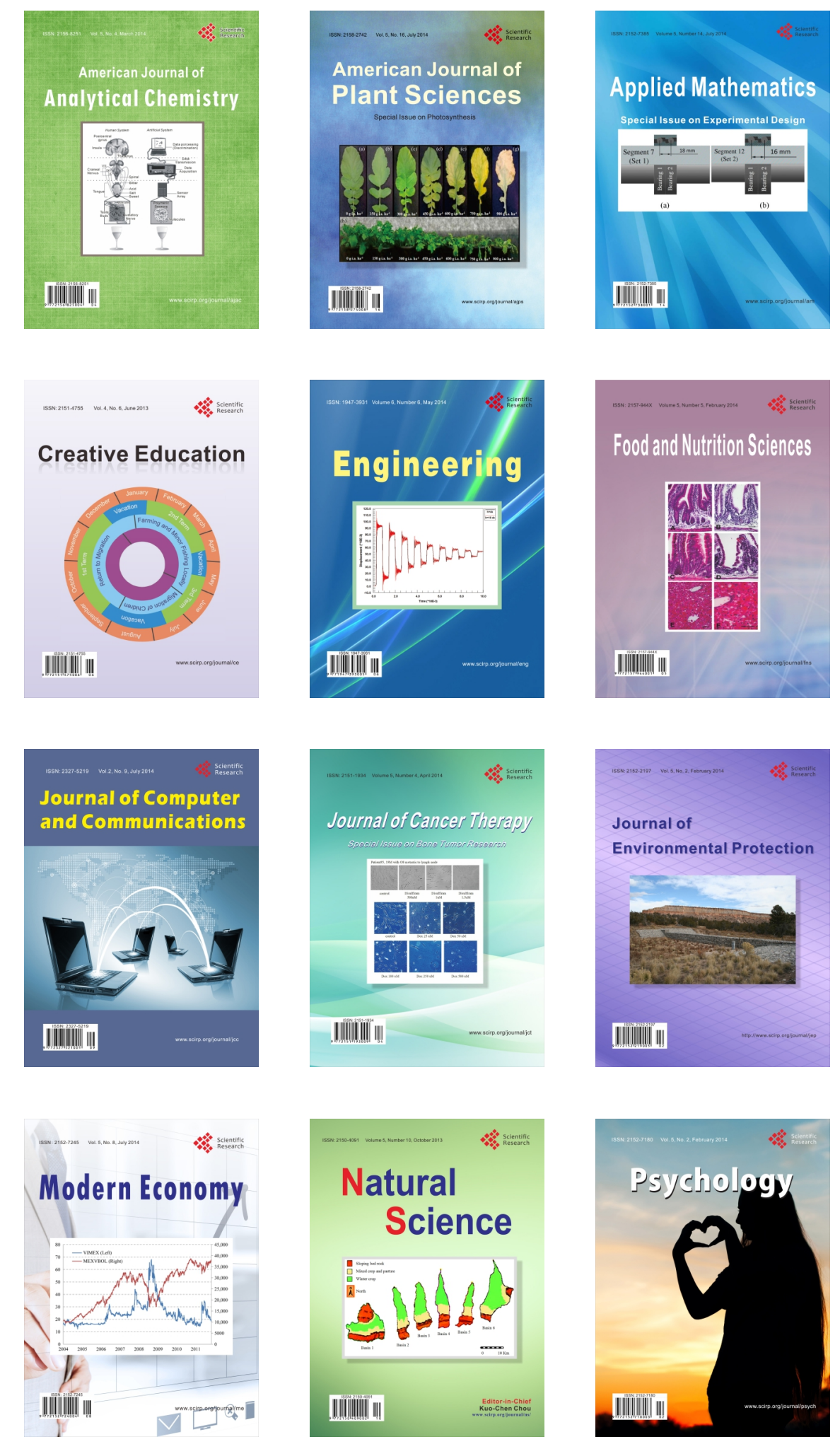